\title{
Evaluation on water bursting risk of working faces near collapse column during the mining process
}

\author{
Yang Xue ${ }^{1,2}$, Huang Jingwu ${ }^{3}$, Wang Hua ${ }^{1,2,4,{ }^{*}}$, Liang Maoliang ${ }^{3}$, Li Wei ${ }^{5,6}$, Zhou Huaqun ${ }^{1,2}$, Zuo Yongjiang ${ }^{1,2}$ \\ ${ }^{1}$ Mine Construction Branch, China Coal Research Institute, 100013 Beijing, China \\ ${ }^{2}$ Beijing China Coal Mine Engineering Company Co., Ltd., 100013 Beijing, China \\ ${ }^{3}$ Shanxian Fengyuan Industrial Co., Ltd., 274300 Heze, China \\ ${ }^{4}$ School of Mining and Geomatics Engineering, Hebei University of Engineering, 056038 Handan, China \\ ${ }^{5}$ Hebei Provincial Technology Innovation Center of Grouting Equipment, 055450 Xingtai, China \\ ${ }^{6}$ Hebei Zhucheng Industrial and Mining Machinery Co., Ltd., 055450 Xingtai, China
}

\begin{abstract}
Collapse column water bursting occurs from time to time in the coal mining process of North China Type Coalfield in China, which causes great economic loss and personal injury. Therefore, great attention must be paid to the harm of collapse column. 1301 working face and 1306 working face in the west wing of No.1 Mining District of Zhangji Coal Mine in Shanxian County are close to No.2 collapse column. Water bursting risk evaluation must be carried out before mining two working faces to ensure safety production. On the basis of fully analyzing the geological and hydrogeological conditions of the $3_{\text {up }}$ coal seam in the west wing of No.1 Mining Area, the "Three Zones(caving zone, water conducted fracture zone and sagging zone) Theory of Coal Seam Roof", "Strata Movement Theory" and "Water Bursting Coefficient Theory" were used respectively to calculate and evaluate the water bursting risk of No.2 collapse column during the course of mining the 1301 working face and 1306 working face. The results show that: firstly, in the process of mining the 1301 working face, the maximum height of the water conducted fracture zone at the closest position of 1301 working face to No.2 collapse column would be $60.20 \mathrm{~m}$, the water bursting coefficient on the boundary of water conducted fracture zone would be $0.066 \sim 0.072 \mathrm{MPa} / \mathrm{m}$, and the water bursting risk of the No.2 collapse column would be smaller; secondly, in the process of mining the 1306 working face, the maximum height of the water conducted fracture zone at the closest position of 1306 working face to No.2 collapse column would be $60.91 \mathrm{~m}$, the water bursting coefficient on the boundary of water conducted fracture zone would be $0.057 \sim 0.089 \mathrm{MPa} / \mathrm{m}$, and the water burst risk of the No.2 collapse column would be small. By August 31, 2020, the 1301 working face had been safely mined more than 200 meters long(exceeding over $120 \mathrm{~m}$ of the closest position in 1301 working face to No. 2 collapse column), and the water bursting did not happen in the working face. This paper can provide a reference for the water prevention and control of similar collapse columns in coal mines.
\end{abstract}

\section{Introduction}

Water bursting in coal mine is considered as one of the major disasters in safety production, and it is also a major safety mining problem faced by coal-producing countries in the world. The geological conditions of China's coal fields are very complex, and the coal reserves threatened by water disaster accounts for $27 \%$ of the proved reserves. Frequent water bursting accidents in mining seriously threaten the safety production of coal mines [1]. According to the water sources of water bursting in coal mines, China's coal mine water disasters are divided into water accident of surface water, accounts for $4.9 \%$ of typical cases of water bursting accidents; water accident of alluvial aquifer, accounts for $1.4 \%$; water accident of sandstone aquifer, accounts for $1.4 \%$; water accident of limestone karst water, accounts for $92.3 \%$. It can be seen that the prevention and control of limestone karst water bursting is the focus of mine water disaster prevention and control [2]. In the limestone karst water accidents, especially the water bursting caused by the collapse column in the North China Coal Field is very destructive and the loss is large [3]. For example, on June 2, 1984, a water bursting disaster occurred in the 2117 working face of Fangezhuang Mine, Kailuan Coal Mining Administration, Hebei Province, China, which was rare in the history of mining in the world. The confined water from the strong aquifer of Ordovician limestone burst into the mine through the collapse column. According to calculations, the average water inflow during the peak period was $123180 \mathrm{~m}^{3} / \mathrm{h}$, and a large mechanized mine with an annual output of 3.1 million tons and had been mined for 20 years was submerged in less than 21 hours.

* Corresponding author: wanghwa@sohu.com 
The loss caused by the water bursting disaster was also huge. The Fangezhuang Mine and Lujiatuo Mine were submerged, the Linxi Mine was all shut down, and the Zhaogezhuang Mine and Tangjiazhuang Mine partially stopped production, resulting in a reduction of 11.417 million tons of coal and a direct economic loss of 495 million Yuan, and 11 workers were killed [4-5]. At $22: 30$ on January 5,1993 , during the process of driving along 7 coal seam in the $-210 \mathrm{~m}$ North Main Roadway at the Guojizhuang Coal Mine in Feicheng Mining Bureau, Shandong Province, the rock sloughing occurred in right wall of the roadway, the floor upheaved, and water burst. The water was ferocious, with a lot of rocks and debris flushing into the roadway, the water inflow was as high as $32970 \mathrm{~m}^{3} / \mathrm{h}$. After 2 hours of the water bursting, the $-210 \mathrm{~m}$ main road was flooded, and after 6 hours and 30 minutes, the whole mine was flooded. The water bursting channel was a combined channel composed of a collapse column and a gentle-dip fault [6]. On March 4, 1996, after cut-through of the new open-off cut of the first working face( 7222 working face) in the Middle $2^{\text {nd }}$ Mining District of Renlou Coal Mine, Wanbei Mining Bureau, Anhui Province, a large amount of water burst from the north side wall of the open-off cut $25 \mathrm{~m}$ from the airway. The initial water inflow was $60 \mathrm{~m}^{3} / \mathrm{h}$, after 3 hours, it was discovered that an about $4 \mathrm{~m} \times 4 \mathrm{~m}$ void had been formed in the coal seam of the northern side of the original water bursting position, and the water outlet had been transferred to a place about 30 $\mathrm{m}$ below the airway. After 4.5 hours, the water inflow reached $1980 \mathrm{~m}^{3} / \mathrm{h}$; and after 6 hours, the water inflow reached $11854 \mathrm{~m}^{3} / \mathrm{h}$. The water inflow was much larger than the designed maximum drainage capacity of $1200 \mathrm{~m}^{3} / \mathrm{h}$, which led to the mine flooding. The water bursting caused a direct economic loss of 158.7549 million Yuan [7]. At 8:47 on April 12, 2003, a hidden water-conducting collapse column was uncovered in driving the lower roadway of 2309 working face of $2^{\text {nd }}$ level(-480 m) in Dongpang Mine of Jinniu Energy Co., Ltd., Hebei Province. On that very day, the peak water inflow was above $7000 \mathrm{~m}^{3} / \mathrm{h}$. Due to overlarge water inflow, on April 17, the entire mine was flooded [8]. And the economic loss amounted to more than 300 million yuan [9]. At 7:29 on March 1, 2010, when the driving face of $870 \mathrm{~m}$ horizontal return main airway of No.16 coal seam in Luotuoshan Coal Mine, China Shenhua Energy Co., Ltd. was close to a hidden small Ordovician limestone water-conducting karst collapse column, water bursting occurred. To 8:40, the water volume reaches $76000 \mathrm{~m}^{3}$, the average water inflow during this period was $65000 \mathrm{~m}^{3} / \mathrm{h}$, and the peak water inflow was as high as $72000 \mathrm{~m}^{3} / \mathrm{h}$. As the water inflow was far greater than the drainage capacity of the mine, the mine was flooded and 32 workers died $[3,10]$. At 14:10 on February 2, 2013, when the open-off cut of 1035 working face in the South No.3 Mining District of Taoyuan Coal Mine, Huaibei Mining (Group) Co., Ltd., Anhui Province was excavated, water burst from the floor of the roadway face, and the water inflow was 10 $\mathrm{m}^{3} / \mathrm{h}$. At 15:30, the floor heave happened in $8 \sim 12 \mathrm{~m}$ backward of excavating face, and the water inflow was $30 \mathrm{~m}^{3} / \mathrm{h}$. At 20:50, the water inflow was about $200 \mathrm{~m}^{3} / \mathrm{h}$.
Subsequently, the water inflow increased rapidly, based on the volume of the flooded roadway $\left(1275000 \mathrm{~m}^{3}\right)$ at $1: 53$ to $6: 10$ on February 3, the water inflow was estimated to reach $29000 \mathrm{~m}^{3} / \mathrm{h}$. The accident caused the entire mine to be flooded and one person died. By drilling the water-blocking boreholes after the accident, it was proved that the water bursting channel was a water-conducting collapse column covered about $20 \mathrm{~m}$ under the 10th coal floor [11]. At 22:51 on May 23, 2017, the water bursting happened in the floor connection roadway of the 12123 working face in Pan'er Mine, Huainan Mining (Group) Co., Ltd., Anhui Province. The initial water inflow was $15 \mathrm{~m}^{3} / \mathrm{h}$, and the water outlet was located $75 \mathrm{~m}$ forward of the roadway gate and $34 \mathrm{~m}$ away from the excavation face, the elevation was $-470 \mathrm{~m}$. Since then, it gradually developed to the excavation face. With the expansion of the water bursting range, the water inflow increased, to $50 \mathrm{~m}^{3} / \mathrm{h}$ at $0: 56$ on May 24; 90 $\mathrm{m}^{3} / \mathrm{h}$ at 19:20; at $16: 28$ on the May 25 , it reached 240 $\mathrm{m}^{3} / \mathrm{h}$; increased to $280 \mathrm{~m}^{3} / \mathrm{h}$ at $20: 00$; and suddenly increased to $3024 \mathrm{~m}^{3} / \mathrm{h}$ at $22: 46$, causing the mine to be flooded. It was estimated that the maximum water inflow was $14520 \mathrm{~m}^{3} / \mathrm{h}$, and the water bursting channel was a concealed collapse column [12].

Due to the great harm caused by water inrush from collapse column in coal mine, three-dimensional seismic exploration must be used to conduct fine survey of the geological structure of the mining area on the basis of mine resource exploration before mining design, and the delineated suspected collapse column shall be drilled for verification, and through theoretical calculations, numerical simulations, similar simulation tests and other methods to analyze the danger of water bursting from the collapse column [9,13-16], a certain width of safety coal pillars are left between the working face and the collapse column; To the working face of its two roadways having been excavated, a certain width of safety coal pillar must be set between the working face and the collapse column on the basis of finding out the characteristics of the collapse column. Thus, the water bursting accident from the collapsed column can be avoided, and the safe production of the coal mine is ensured.

The $3_{\text {up }}$ coal seam is mined in the No.1 Mining District of Zhangji Coal Mine in Shanxian County, Shandong Province, China. In 2007, the No.2 collapse column was found in the three-dimensional geological exploration of the Mining Area [7]; in 2017, in excavating the belt roadway of 1305 working face the collapse column was exposed without water. As of the end of December 2019, the open-off cut of 1301 working face had been excavated holing-through. The working face is located to the north of the No.2 collapse column. It was planned to mine at the end of February 2020; the designed 1306 working face is located to the south of the No. 2 collapse column and is planned to mine at March 2021. Has 1305 face mining resulted in "activation" of the collapse column? In order to ensure the safety mining of the 1301 working face and 1306 working face, it is necessary to evaluate the water bursting risk of No.2 collapse column. 


\section{Overview of the Zhangji Coal Mine and the west wing of No.1 Mining District}

\subsection{Overview of the Zhangji Coal Mine}

\subsubsection{Location, traffic and production scale of the mine}

Zhangji Coal Mine is located about $22 \mathrm{~km}$ east of Shanxian County, Heze City, Shandong Province. The administrative division is under the jurisdiction of Zhangji Town, Shanxian County. Shanxian County is located at the junction of the four provinces of Jiangsu, Shandong, Henan and Anhui, with the surrounding national highways and provincial highways crisscrossed. Zhangji Coal Mine is about $21 \mathrm{~km}$ west of China National Highway 105, and about $6 \mathrm{~km}$ south of Provincial Highway 349 (Heze-Fengxian), there are county and township roads from Zhangji to Shanxian, Zhongxingji and other counties in the area, the road traffic is very convenient; the mine is about $70 \mathrm{~km}$ of Caoxian Station of Beijing-Kowloon Railway and about $80 \mathrm{~km}$ northwest of Heze Station of Beijing-Kowloon Railway, the railway transportation is convenient too; the mine is $50 \mathrm{~km}$ east of the Beijing-Hangzhou Grand Canal, which will provide good waterway transportation conditions for coal export. The traffic location of Zhangji Coal Mine is shown in Figure 1.

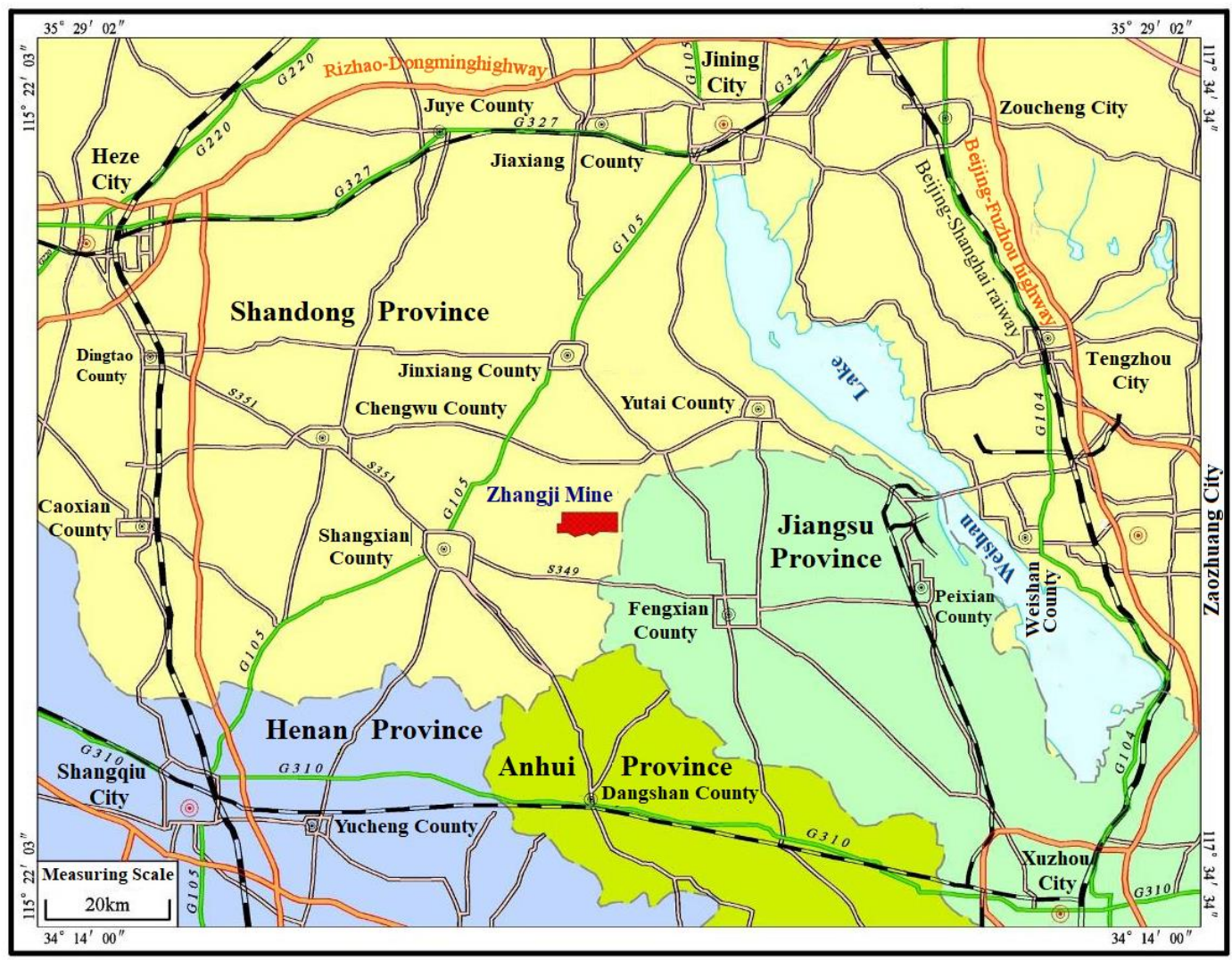

Fig. 1. Traffic location map of Zhangji Coal Mine

The mine field is $9.90 \mathrm{~km}$ long from east to west, $4.07 \mathrm{~km}$ wide from north to south, with an area of 32.897 $\mathrm{km} 2$, and the mining elevation is $-400 \sim-1200 \mathrm{~m}$. The extreme geographical coordinates of the mining area are east longitude $116^{\circ} 17^{\prime} 30^{\prime \prime} \sim 116^{\circ} 24^{\prime} 00^{\prime \prime}$ and north latitude $34^{\circ} 48^{\prime} 44^{\prime \prime} \sim 34^{\circ} 51^{\prime} 00^{\prime \prime}$. The designed production capacity of the mine is 1.2 million $\mathrm{t} / \mathrm{a}$, and the service life is 52 years. The mine started construction in December 2011 and officially put into production in July 2016 [17].

\subsubsection{Mine geology}

\section{(1) Strata}

The strata exposed by drilling engineering and roadway exploration engineering in the mine field are from old to new: Ordovician Majiagou Formation,
Carboniferous Yuemengou Group Benxi Formation, Carboniferous-Permian Yuemengou Group Taiyuan Formation, Permian The Yuemengou Group Shanxi Formation, Permian Shihezi Formation, Paleogene, Neogene and Quaternary strata.

\section{(2) Coal seams}

The coal-bearing strata in the mine field are Shanxi formation and Taiyuan Formation.

(1) Shanxi Formation

Shanxi formation is one of the main coal-bearing strata in the mine field, which contains three minable coal seams (2, 3up and 3lower), they are most minable coal seams.

\section{(2) Taiyuan Formation}

According to the characteristics of the lithological combination, this group can be divided into three sections: upper, middle and lower sections. 
The upper section(the top boundary of the Taiyuan Formation to the top boundary of $5^{\text {th }}$ limestone) contains 3 thin coal seams $(5,6,8)$, all of them are thin coal seams and none of them are mineable (only the 8 coal seam has 1 mineable point, i.e. coal thickness at hole $\mathrm{ZKm} 3$ is $0.90 \mathrm{~m})$

The middle section (the top boundary of $5^{\text {th }}$ limestone to the top boundary $10^{\text {th }}$-upper limestone) contains 6 thin coal seams $\left(9,10_{\text {up }}, 10_{\text {lower }}, 12_{\text {lower }}, 13,15_{\text {up }}\right)$, all of them are thin coal seams. Except for the $12_{\text {lower }}$ coal seam is mostly mineable, the other coal seams are not mineable.

The lower section (the top boundary of $10^{\text {th }}$-upper limestone to the top boundary of $12^{\text {th }}$ limestone) contains 4 coal seams $\left(15_{\text {lower }}, 16_{\text {up }}, 17,18_{\text {up }}\right)$, except for $15_{\text {lower }}$ coal seam is not mineable, the remainder coal seams are most mineable or partially mineable thin coal seams in the occurrence area.

\subsubsection{Mine hydrogeology}

The main aquifers in the mine field include Quaternary loose aquifer, Paleogene conglomerate aquifer, 3 coal seam roof and floor sandstone fractured aquifer, $3^{\text {rd }}$ limestone karst fractured aquifer, $10^{\text {th }}$-lower limestone karst fractured aquifer, Ordovician limestone aquifer. A large area of concealed outcrop of bedrock aquifer under the Quaternary alluvial layer in the southern part of the minefield is supplied by sand water from the lower aquifer section of the Quaternary. The mine hydrogeological condition belongs to medium type. The current normal water inflow of the mine is about $60 \mathrm{~m}^{3} / \mathrm{h}$, and the maximum water inflow over the years was 205.3 $\mathrm{m}^{3} / \mathrm{h}[17]$.

\subsection{Overview of the west wing of No.1 Mining District in Zhangji Coal Mine}

\subsection{1 $3_{\text {up }}$ coal seam and its mining situation}

The west wing of No.1 Mining District is located on the west side of the three blind inclined shafts of the mine(track blind inclined shaft, belt blind inclined shaft and return air blind inclined shaft), it is the first mining district of the mine. It was put into mining in July 2016 and has been mined 3 up coal seam. According to the disclose of prospecting bores, excavation engineering and mining engineering, the thickness of the $3_{\text {up coal }}$ seam in the No.1 Mining District is $2.19 \sim 7.64 \mathrm{~m}$, the average thickness is $5.60 \mathrm{~m}$, and the seam floor elevation is about -550 -900m(buried depth is about 590 940m); its immediate roof is fine sandstone, siltstone and sandy mudstone, thickness is $10.19 \sim 14.92 \mathrm{~m}$, the roof average thickness is $11.79 \mathrm{~m}$; and its floor is mudstone, sandy mudstone, thickness $1.93 \sim 8.21 \mathrm{~m}$, average thickness is $4.39 \mathrm{~m}$.

By the end of December 2020, three working faces of 1302, 1305 and 1303 had been mined successively. The holing-through excavation in open-off cut of 1301 working face had been completed, and it is expected to start mining at the end of February 2020. It is planned to arrange the 1306 working face near the 1305 working face with a $5 \mathrm{~m}$ coal pillar between the working face and the goaf of the 1305 working face (Fig. 2).

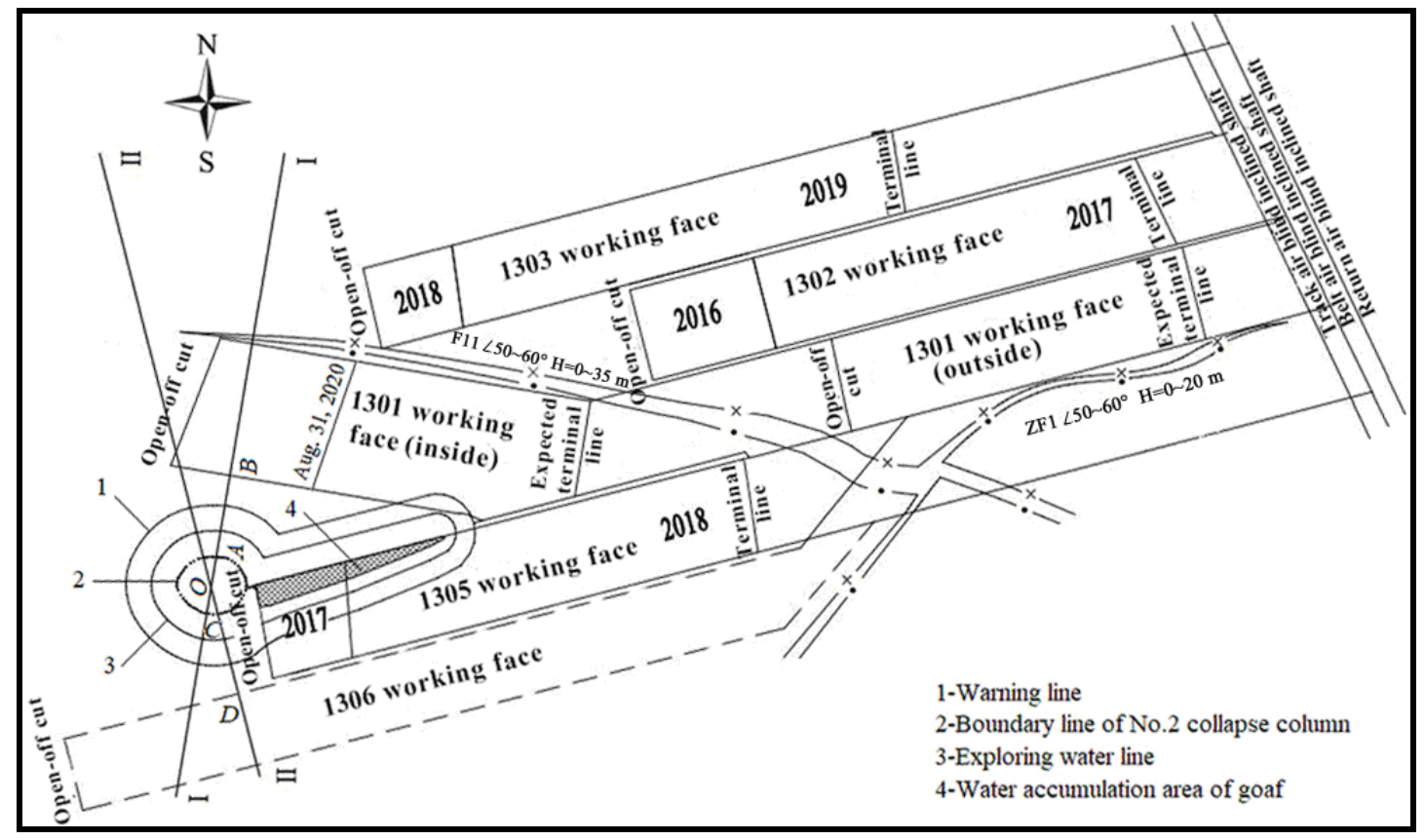

Fig. 2. The working faces' layout of 3up coal seam in the West Wing of No.1 Mining Area in Zhangji Coal Mine

\subsubsection{Collapse column}

In June 2017, an abnormal geologic area was exposed during the excavation of the belt roadway of 1305 working face. Transient electromagnetic detection and 4 underground water detection holes verified that the abnormal geologic area is a collapse column (No.2 collapse column). The collapsed column is nearly oval, with a major axis of about $110 \mathrm{~m}$ and a minor axis of 
about $90 \mathrm{~m}$ (Fig. 2), and an area of about $7791 \mathrm{~m}^{2}$. The collapse column is mainly composed of sandstone, mudstone and other rock blocks. The rock blocks are mixed in size and angular, and compacted and cemented tightly. 4 water detection boreholes were all no water, this indicated that the collapse column is weak in watery at that time.

\section{Risk analysis of water bursting in mining of 1301 and 1306 working faces by No.2 collapse column}

By the end of 2019, the 1305 working face had been mined for more than 2 years. The goaf close to the No. 2 collapse column had an accumulated water area of 7612 $\mathrm{m}^{2}$ and the accumulated water volume was $16,378 \mathrm{~m}^{3}$. Since the accumulated water goaf of 1305 working face is connected to the No.2 collapse column, will the hydrogeological characteristics of the No.2 collapse column be changed under the long-term action of the water in the goaf? Does the No.2 collapse column have a water bursting risk to the 1301 and 1306 working faces to be mined? These two problems are problems demanding prompt solution in mine safety production.

Due to the tight succession of mine production, the detection of No.2 collapse column through underground drilling in the track roadway of 1305 working face has safety risk and affects production continuity. There are problems such as high detection cost and long construction period(site requisition, drilling, pumping test or water injection test, etc.) in ground drilling holes detection, which also affect production continuity. Therefore, it is assumed that under the long-term influence of water accumulation in the goaf of 1305 working face, No. 2 collapse column has become a waterrich collapse column and has a hydraulic connection with the lower Ordovician limestone aquifer. On this basis, the risk of water inrush of No.2 collapse column for mining at 1301 working face and 1306 working face is analyzed respectively. If there is no danger of water bursting, mining should be arranged according to the design; if there is danger of water bursting, the corresponding measures of water prevention and control should be studied.

\subsection{Risk analysis of water bursting in mining of 1301 working face by No. 2 collapse column}

Affected by fault F11: $\angle 50 \sim 60^{\circ} \mathrm{H}=0 \sim 35 \mathrm{~m}, 1301$ working face is separated into two working faces: 1301 working face (inside) and 1301 working face (outside), 1301 working face (inside) is close to No.2 collapse column(Fig. 2).

The 1301 working face(inside) is located to the north of No.2 collapse column with a minimum horizontal distance of about $125 \mathrm{~m}$. Points A and B are respectively located at the outer edge of the No. 2 collapse column and the outer edge of the track roadway of 1301 working face(inside), and the two points are the closest points between the working face and the collapse column. The straight line passing through the two points is the I-I section line(Fig. 2), Figure 3 is the I-I geological section. The 1301 working face(inside) starts from protective coal(rock) pillar line of No.1 Mining District in the west, to the B1 hole in the east, to the F11 fault in the north, and to the 1305 working face in the south. The working face is $605 \sim 664 \mathrm{~m}$ long from east to west and 152 220 $\mathrm{m}$ wide from north to south. The thickness of 3 up coal is $6.30 \mathrm{~m}(\mathrm{~B} 1 \mathrm{hole}$, located in the working face), and the coal roof is mainly composed of fine sandstone, siltstone and sandy mudstone, generally, it belongs to mediumhard rock. According to the literature[18], after the coal seam mining, the height of the water conductive fracture zone is calculated as follows:

$$
H_{\mathrm{li}}=\frac{100 \sum M}{1.6 \sum M+3.6} \pm 5.6
$$

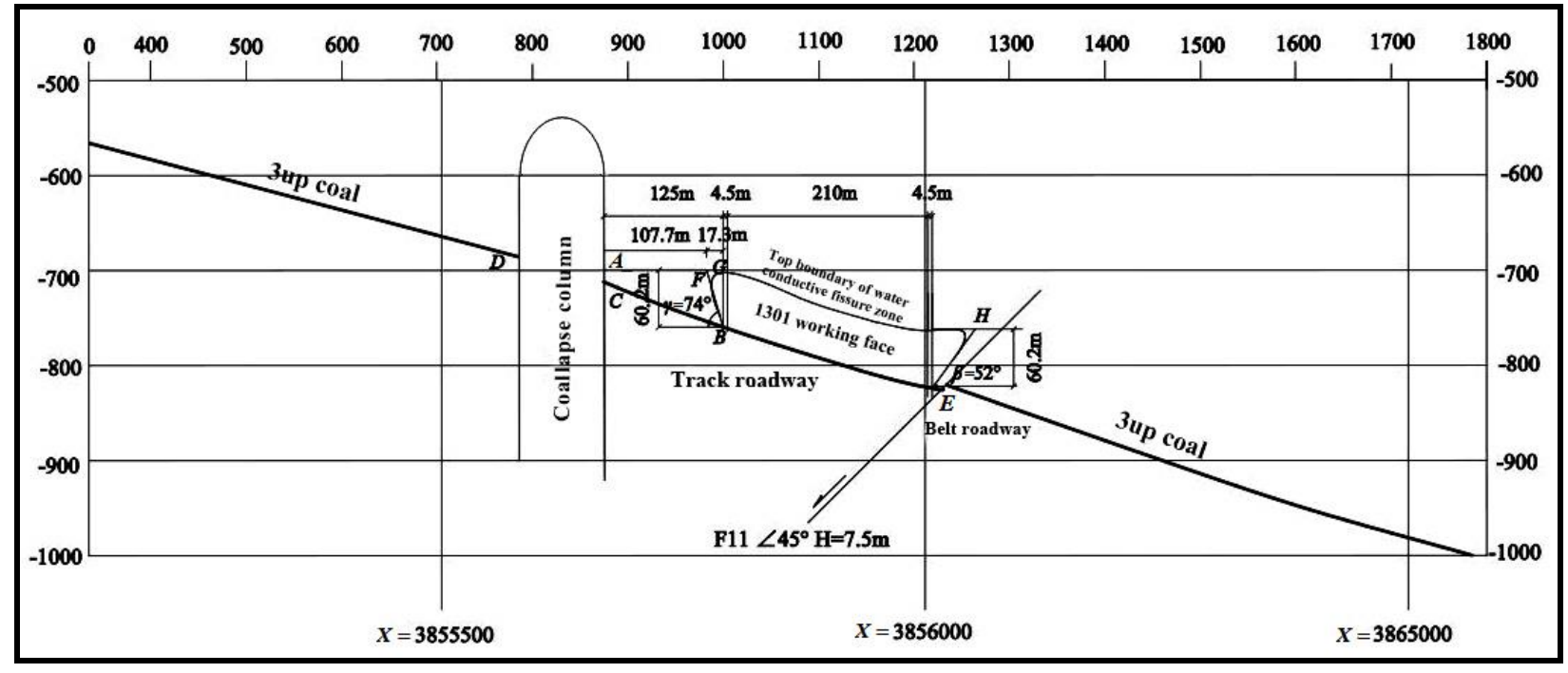

Fig. 3. Geological section map of I-I line

Or 


$$
H_{\mathrm{li}}=20 \sqrt{\sum M}+10
$$

Where, $H_{l i}$ is height of water flowing fractured zone, $\mathrm{m} ; \sum M$ is the total mining thickness, $\mathrm{m}$; “ \pm ” is medium error("+" value will be taken here).

Put $\sum M=6.30$ into equation (1) and equation (2) respectively, then:

$$
\begin{aligned}
H_{\mathrm{li}} & =\frac{100 \sum M}{1.6 \sum M+3.6}+5.6=\frac{100 \times 6.3}{1.6 \times 6.3+3.6}+5.6 \\
& =51.65(\mathrm{~m}) \\
H_{\mathrm{li}} & =20 \sqrt{\sum M}+10=20 \sqrt{6.3}+10 \\
& =60.20(\mathrm{~m})
\end{aligned}
$$

Or

To ensure safety, the authors adopted $H_{\mathrm{li}}=60.20 \mathrm{~m}$.

Referring to the literature[19], the rock raise collapse angle $\gamma$ was $74 \sim 88.4^{\circ}\left(74^{\circ}\right.$ was taken here) in mining the Carboniferous-Permian coal seams of Zaozhuang Mining Area and Xinwen Mining Area near Zhangji Coal Mine, and the rock dip collapse angle $\beta$ was $52 \sim 76.5^{\circ}\left(52^{\circ}\right.$ was taken here). Thus, in the mining process of 1301 working face(inside), the horizontal distance $F G$ (Figure 2) between the highest point $F$ of the water-conducting fissure zone at point $B$ of the track roadway and the outer wall of the track roadway would be obtained:

$$
F G=G B \cdot \cot \gamma=60.20 \times \cot 74^{\circ}=17.30 \quad(\mathrm{~m})
$$

Horizontal distance $F A$ between point $F$ and the outer edge point $A$ of No.2 collapse column:

$$
F A=G A-F G=125-17.30=107.70(\mathrm{~m})
$$

According to the regional data, the total thickness of Ordovician limestone is more than $650 \mathrm{~m}$, and the maximum thickness revealed in this mine field was $54.67 \mathrm{~m}$ (B1 hole). The quality was pure, and the karst fissure was relatively developed. No borehole leakage has occurred in the boreholes pass through this layer in the mine field. According to the water pumping test of Ordovician limestone with 3 boreholes (B1, B2, Zk1-2) in the mine field, the water level elevation was $-4.50 \sim$ $+19.13 \mathrm{~m}$, the unit water inflow was $0.00004 \sim 0.005$ $\mathrm{L} /(\mathrm{s} \cdot \mathrm{m})$, and the permeability coefficient was $0.00005 \sim$ $0.008 \mathrm{~m} / \mathrm{d}$. The pumping test showed that the aquifer had weak water abundance. There were 5 boreholes in the mine field to expose its top, and the distance between the Ordovician limestone and the $3_{\text {up }}$ coal seam was $183 \sim$ $212 \mathrm{~m}$, with an average of $199.1 \mathrm{~m}$.

The elevation of the $3_{\text {up }}$ coal roof at point $B$ is about $760 \mathrm{~m}$, so the elevation of point $F$ is $-699.8 \mathrm{~m}$. If the No.2 collapse column is connected to Ordovician limestone aquifer, the water bursting coefficient at point $F$ is:

$$
T=\frac{p}{M-10}
$$

Where, $T$ is water bursting coefficient, $\mathrm{MPa} / \mathrm{m} ; p$ is the actual water head value received by the coal seam bottom water-resisting layer(the water pressure should be calculated from the top interface of the aquifer, and the water level value shall be the highest value of the water level observed in the aquifer in the past 3 years),
MPa; $M$ is thickness of the coal seam bottom waterresisting layer, $\mathrm{m}$.

Thereby,

(1) Water bursting coefficient at point $F$ would be:

$$
\begin{aligned}
T_{\mathrm{F}} & =\frac{p_{\mathrm{F}}}{M_{\mathrm{F}}-10}=\frac{p_{\mathrm{F}}}{F A-10} \\
& =\frac{1 \times 1000 \times 9.8 \times[19.13-(-699.8)] \times 10^{-6}}{107.70-10} \\
& =0.072(\mathrm{MPa} / \mathrm{m})
\end{aligned}
$$

(2) Water bursting coefficient at point $B$ would be:

$$
\begin{aligned}
T_{\mathrm{B}} & =\frac{p_{\mathrm{B}}}{M_{\mathrm{B}}-10}=\frac{1 \times 1000 \times 9.8 \times[19.13-(-760)] \times 10^{-6}}{125-10} \\
& =0.066(\mathrm{MPa} / \mathrm{m})
\end{aligned}
$$

The literature[20] pointed out that "from the actual data of the whole China, the water bursting coefficient of the section where the floor is structurally damaged shall generally not be greater than $0.06 \mathrm{MPa} / \mathrm{m}$, and the section where the water-resisting layer is intact without fault structure damage shall not be greater than 0.1 $\mathrm{MPa} / \mathrm{m}$ ". According to the plan view of the coal mining project in 3 up coal seam(Fig. 2), there is no obvious fault structure between the 1301 working face(inside), its track roadway and the No.2 collapse column. It could be regarded as a complete section of the formation, and the critical water bursting coefficient can be $0.1 \mathrm{MPa} / \mathrm{m}$. The tow points' water bursting coefficients would be all less than $0.08 \mathrm{MPa} / \mathrm{m}$, and the No. 2 collapse column would have basically no water bursting threat to the coal seam mining in the 1301 working face(inside).

\subsection{Risk analysis of water bursting in mining of 1306 working face by No.2 collapse column}

The 1306 working face is located to the south of No.2 collapse column, and the minimum horizontal distance is about $124 \mathrm{~m}$. The working face starts from protective coal(rock) pillar line of No.1 Mining District in the west, and is connected to the 1305 working face in the north. The east and south sides are respectively adjacent to the general return airway of the west wing of No.1 Mining District. The working face is $1159 \sim 1204 \mathrm{~m}$ long from east to west, and $120 \mathrm{~m}$ wide from north to south. The thickness of the $3_{\text {up }}$ coal seam in the west section of the working face is $6.48 \mathrm{~m}(\mathrm{ZK} 11-2$ hole, located in the working face), and the coal roof is mainly composed of fine sandstone, siltstone, and sandy mudstone, generally, it belongs to medium-hard rock.

Put $\sum M=6.48$ into equation (1) and equation (2) respectively, then:

$$
\begin{aligned}
H_{\mathrm{li}} & =\frac{100 \sum M}{1.6 \sum M+3.6}+5.6=\frac{100 \times 6.48}{1.6 \times 6.48+3.6}+5.6 \\
& =51.99(\mathrm{~m})
\end{aligned}
$$

Or

$$
H_{\mathrm{li}}=20 \sqrt{\sum M}+10=20 \sqrt{6.48}+10=60.91 \quad(\mathrm{~m})
$$

To ensure safety, the authors adopted $H_{\mathrm{li}}=60.91 \mathrm{~m}$.

Points $C$ and $D$ are respectively located at the outer edge of the No. 2 collapse column and the outer edge of 
the track roadway of 1306 working face, and the two points are the closest points between the working face and the collapse column. The straight line passing through the two points is the II-II section line(Fig. 2), Figure 4 is the II-II geological section. Thus, in the process of mining at 1306 working face, the horizontal distance $K N$ between the highest point $K$ of the water conductive fissure zone at point $D$ of the track roadway and the point $D$ at outer wall of the track roadway(Fig. 4) would be:

$$
K N=D J \cdot \cot \gamma=60.91 \times \cot 52^{\circ}=47.59(\mathrm{~m})
$$

The horizontal distance $K H$ between point $K$ and Point $C$ at the outer edge of No. 2 collapse column would be:

$$
H K=H N-K N=124-47.59=76.41 （ \mathrm{~m})
$$

The $3_{\text {up }}$ coal roof elevation of Point $D$ is about -645 $\mathrm{m}$, and the elevation of point $K$ is $-584.09 \mathrm{~m}$.

Consequently,

(1) Water bursting coefficient at point $K$ would be:

$$
\begin{aligned}
T_{\mathrm{K}} & =\frac{p_{K}}{M_{K}-10}=\frac{p_{K}}{K H-10} \\
& =\frac{1 \times 1000 \times 9.8 \times[19.13-(-584.09)] \times 10^{-6}}{(124-47.59)-10} \\
& =0.089(\mathrm{MPa} / \mathrm{m})
\end{aligned}
$$

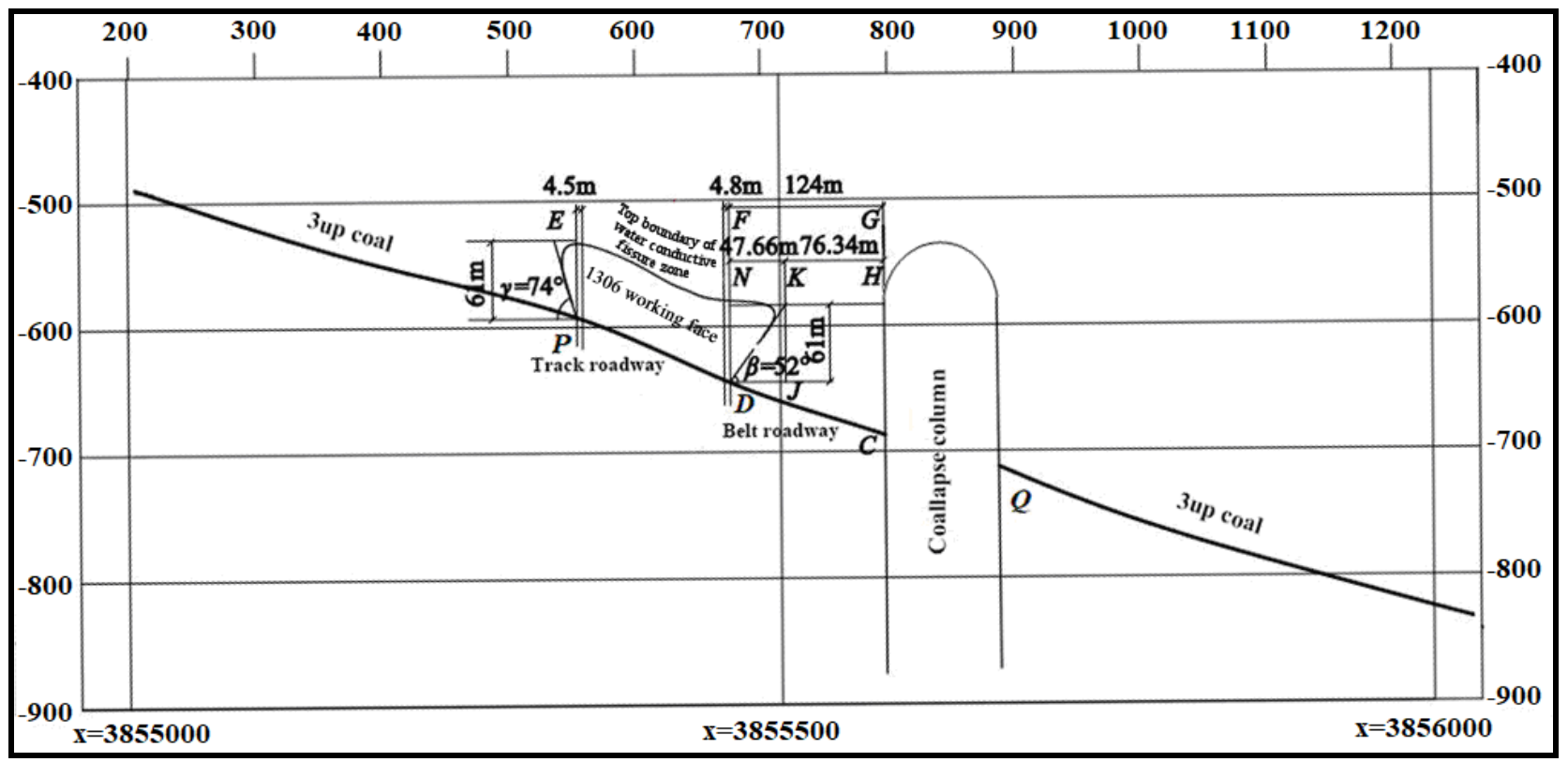

Fig. 4. Geological section map of II-II line

(2) Water bursting coefficient at point $D$ would be:

$$
\begin{aligned}
T_{D} & =\frac{p_{D}}{M_{D}-10}=\frac{1 \times 1000 \times 9.8 \times[19.13-(-645)] \times 10^{-6}}{124-10} \\
& =0.057(\mathrm{MPa} / \mathrm{m})
\end{aligned}
$$

According to the plan view of the coal mining project in $3_{\text {up }}$ coal seam(Fig. 2), there is no obvious fault structure between the western section and neighbouring belt roadway of 1306 working face and the No.2 collapse column. It could be regarded as a complete section of the formation, and the critical water bursting coefficient can be $0.1 \mathrm{MPa} / \mathrm{m}$. The tow points' water bursting coefficients would be all less than $0.09 \mathrm{MPa} / \mathrm{m}$, and the No. 2 collapse column would have smaller water bursting threat to the coal seam mining in the 1306 working face.

\section{1 working face(inside) mining situation}

The 1301 working face(inside) started mining on April 10, 2020, using longwall mining on the strike and fullymechanized top coal caving technology. As of August 31, 2020, $227.5 \mathrm{~m}$ had been mined along the track roadway, had passed $B$ point(the nearest point of the mining face to No. 2 collapse column) about $120 \mathrm{~m}$; and $214.2 \mathrm{~m}$ has been mined along the belt roadway. During the mining period, no water came out in the working face.

\section{Conclusions and suggestions}

Aiming at the problem of whether there would be water bursting risk in mining 1301 working face and 1306 working face of the west wing of No.1 mining District in Zhangji Coal Mine, Shanxian County, Shandong Province, China, because of these two working face approaching No. 2 collapse column, the authors analyzed and evaluated the risk of water bursting from the collapse column by the method of theoretical calculation; and the evaluation results were used to guide the mining 1301 working face, as of August 31, 2020, the working face safely mined though $B$ point(the point of maximum water inrush coefficient in 1301 working face) exceeding over $120 \mathrm{~m}$. The main conclusions and suggestions were as follows:

(1) During the mining process of 1301 working face, the maximum height of the coal roof water conductive fissure zone would be $60.20 \mathrm{~m}$, the maximum water 
bursting coefficient would be $0.072 \mathrm{MPa} / \mathrm{m}$, and the water bursting risk would relatively small.

(2) During the mining process of 1306 working face, the maximum height of the coal roof water conductive fissure zone would be $60.91 \mathrm{~m}$, the maximum water bursting coefficient would be $0.089 \mathrm{MPa} / \mathrm{m}$, and the risk of water inrush would be small.

(3) When design and arrange the working faces near the collapse column, the geological and hydrogeological characteristics of the collapse column must be prospected clearly, and the water bursting risk analysis and evaluation must be carried out to ensure the safe and efficient production of the coal mine.

\section{Acknowledgments}

This work was financially supported by the Science and Technology Innovation and Entrepreneurship Special Fund of China Coal Technology \& Engineering Group(Grant No.2018MS026), the Key Technologies Project for Prevention and Control of Serious and Major Accidents in Safety Production of State Administration of Work Safety of the People's Republic of China (Grant No.yangqi-0012-2017AQ), the authors are grateful for these supports.

\section{References}

1. LI Zhenhua, XU Gaoming, LI Jianbo. Research status and outlook of water-inrush from collapse column in China[J]. China Mining Magazine, 2009, 18(4): 107-109.

2. YU Jingcun, LIU Zhixin, LIU Shucai, et al. Theoretical analysis of mine transient electromagnetic method and its application in detecting water burst structures in deep coal stope[J]. Journal of China Coal Society, 2007, 32 (8) : 818821. (in Chinese)

3. NIU Xiuqing, WANG Hua, LIU Shujie. Application and development trends on grouting reconstruction technology for floor karst aquifers of lower group coal seam in Northern China Coal Field[J]. Mine Construction Technology, 2017, 38 (3) : 24-30.

4. Kailuan Coal Mining Administration, Geological Exploration Branch of China Coal Research Institute, Mine Construction Branch of China Coal Research Institute. Control of very heavy water inrush from sink holes connecting with ordovician limestone(I)[J]. Coal Science and Technology, 1986 (1) : 6-14+64.

5. ZHU Jiwei. The catastrophic water inrush disaster of Ordovician limestone karst collapse column in Fangezhuang Mine of Kailuan Mining Bureau of Hebei Province and its treatment[A]// Youth Work Professional Committee of Chinese Society of Rock Mechanics and Engineering, Accident Professional Committee of Chinese Society of Rock Mechanics and Engineering. Record of accident and disaster in rock engineering(I)[C]. Beijing: Chinese Society of Rock Mechanics and Engineering, 1994: 83-102.

6. ZHANG Yong-shuang, QU Yong-xin, LIU Guo-lin, et al. Some problems of karst collapse posts in North-China-type coalfields[J]. Journal of Engineering Geology, 2000, 8(1): 35-39.

7. CHEN Zhaoxuan, WU Yuhua. Introduction to water bursting and treatment in Renlou Mine[J]. Mine Design, 1998(2): 18-20.

8. LIU Jiangong, ZHAO Qingbiao, BAI Zhongsheng, et al. Rapid holding and control for special large water inrush from sink hole in Dongpang Mine[J]. Coal Science and Technology, 2005, 33(5): 4-7.

9. YIN Shangxian, LIAN Huiqing, LIU Demin, et al. 70 years of investigation on karst collapse column in North China Coalfield: cause of origin, mechanism and prevention[J]. Coal Science and Technology, 2019, 47(11): 1-29.

10. ZHANG Wenzhong. Three-dimension large-scale simulation experimental research on water inrush of collapse column[J]. Journal of Taiyuan University of Technology, 2015, 46(6): 685-690.

11. Investigation Team of "Feb. 3" water inrush accident in Taoyuan Coal Mine. Investigation Report of "Feb. 3" water inrush accident in Taoyuan Coal Mine of Huaibei Mining (Group) Co., Ltd[R]. Huaibei: Huaibei Branch of Anhui Coal Mine Safety Supervision Bureau, 2013.

12. GAN Lintang. Prevention of limestone water in coal floor of group A of Huainan Mining Area and causes analysis of water inrush accidents in Pan'er Mine[J]. Safety in Coal Mines, 2018, 46(7): 171-174.

13. Yang Tianhong, Shi Wenhao, Liu Honglei, et al. A non-linear flow model based on flow translation and its application in the mechanism analysis of water inrush through collapse pillar[J]. Journal of China Coal Society, 2017, 42(2): 315-321.

14. YAO Banghua, WANG Liancheng, WEI Jianping, et al. A deformation-seepage-erosion coupling model for water outburst of Karst collapse pillar and its application[J]. Journal of China Coal Society, 2018, 43(7): 2007-2013.

15. ZHANG Wenzhong. Three-dimension large-scale simulation experimental research on water inrush of collapse column[J]. Journal of Taiyuan University of Technology, 2015, 46(6): 685-690.

16. SONG Yanqi, WANG Xingyu, CHENG Peng, et al. The mechanical criterion and numerical simulation of thick-walled elliptical cylinder collapse column model under water inrush[J] Journal of China Coal Society, 2011, 36(3): 452-455.

17. LIANG Maoliang, GONG Lingwei, LI Qiming, et al. Report of mine hydrogeological type division in Shanxian Fengyuan Industrial Co., Ltd[R]. Heze: Shanxian Fengyuan Industrial Co., Ltd., 2018.

18. State Administration of Work Safety of China, National Coal Mine Safety Administration of China, National Energy Administration of the China, et al. 
Standard of pillar leaving and coal mining under building, water, railway and mail shaft and tunnel[M]. Beijing: China Coal Industry Publishing House, 2017.

19. State Coal Industry Bureau. Regulations of pillar leaving and coal mining under building, water, railway and mail shaft and tunnel[M]. Beijing: China Coal Industry Publishing House, 2000.

20. State Administration of Coal Mine Safety of China. Detailed rules and regulations on water prevention and control in coal mines[S]. Beijing: China Coal Industry Publishing House, 2018. 